\title{
Federal transfers, inequality, and redistribution: Contrasting theories and empirical evidence for five Latin American cases
}

\section{Lucas I. González}

To cite this article: Lucas I. González (2018): Federal transfers, inequality, and redistribution: Contrasting theories and empirical evidence for five Latin American cases, Regional \& Federal Studies, DOI: 10.1080/13597566.2018.1511981

To link to this article: https://doi.org/10.1080/13597566.2018.1511981

Published online: 22 Aug 2018.

Submit your article to this journal ¿

View Crossmark data ¿ 


\title{
Federal transfers, inequality, and redistribution: Contrasting theories and empirical evidence for five Latin American cases
}

\author{
Lucas I. González ${ }^{\mathrm{a}, \mathrm{b}, \mathrm{c}}$ \\ ${ }^{a}$ Consejo Nacional de Investigaciones Cientificas y Tecnicas, Buenos Aires, Argentina; \\ bepartment of Political Science, Pontificia Universidad Catolica Argentina, Buenos Aires, \\ Argentina; 'School of Politics and Government, Universidad Nacional de San Martin, Buenos \\ Aires, Argentina
}

\begin{abstract}
Does federalism encourage inequality? Or, do transfers from the central government augment redistribution? This research examines whether variation in the institutional structures as well as the mechanisms and criteria for the distribution of fiscal resources in Argentina, Brazil, Chile, Colombia, and Mexico affect interregional and interpersonal inequality. Using descriptive statistics and regression models for original panel data from these five cases between 1983 and 2013 , the study finds that a more progressive redistributive capacity of the central government is statistically associated with improvements in interregional as well as interpersonal equity, challenging the conventional view that federalism reinforces inequality. The article discusses these findings and others from competing arguments, and explores their implications for the discussion on inequality and redistribution in developing nations.
\end{abstract}

KEYWORDS Federalism; federal transfers; inequality; redistribution; Latin America

\section{Introduction}

Most Latin American countries reduced sharply their inequality during the last decade, while income inequality increased sharply in other parts of the world (Lustig, Lopez-Calva, and Ortiz-Juarez 2013, 119). Between 2001 and 2014, Argentina and Brazil decreased their Gini coefficients by ten and thirteen points, from 53 to 43 and 64 to 51 , respectively. Despite recent improvements in income and reductions in inequality, countries in this region still have substantial disparities among them. Argentina, Chile, and Uruguay have gross domestic products (GDP) per capita (PPP) six times larger than Nicaragua and Honduras, and more than eighteen times that of Haiti's.

CONTACT Lucas I. González Igonzalez@unsam.edu.ar, lucas_gonzalez@uca.edu.ar @ Consejo Nacional de Investigaciones Cientificas y Tecnicas, Buenos Aires C1033AAJ, Argentina; Pontificia Universidad Catolica Argentina, Buenos Aires C1107AAZ, Argentina

(7) Supplemental data for this article can be accessed here https://doi.org/10.1080/13597566.2018. 1511981

(c) 2018 Informa UK Limited, trading as Taylor \& Francis Group 
This large variation is not only observed among countries of the region, but also within many of them. ${ }^{1}$ Casanare is the richest oil-producing department in Colombia. Its GDP per capita is 9.3 times larger than Vaupés's, the poorest, mostly indigenous, Colombian department located in the Amazon rainforest (1610 versus 14,988 USD per capita). In Brazil, Piaui's GDP per capita is 9.7 times lower than the Federal District's (Brasília) (2092 versus 20,343 USD per capita). Formosa, one of the poorest Northern Argentine provinces, has a GDP per capita more than 10 times lower than the City of Buenos Aires (2256 versus 23,439 USD) (See Table A1, Appendix for Data Sources).

Inequality within provinces and states is also enormous. Tierra del Fuego is very equal for Latin American standards, with a provincial Gini index of 0.32 (in 2011), similar to Canada and Australia (in 2011 and 2012, respectively). On the other hand, Salta and Corrientes are the most unequal provinces in Argentina, with Gini indices of 0.45 and 0.46 , respectively, similar to Guatemala, Malawi, and Paraguay (in 2014, 2010, and 2013, respectively). Brazil shows similar inequality within states, ranging from relatively equal states (Santa Catarina has a Gini of 0.435 in 2013) to very unequal ones (Brasilia has a Gini of 0.578 in 2013) (See Table A1, Appendix).

The literature on the determinants of inequality has long claimed that federalism tends to produce less redistribution and, as a consequence, more disparity across regions than unitary cases (Lowi 1984, 379; Wildavsky 1984, 68; Rodden 2009, 2-3; see Beramendi 2012, 4 for a review). Despite this agreement in part of the literature, several studies have documented a large variation in the degree of redistribution achieved in developed federal democracies (Obinger, Leibfried, and Castles 2005) or in the redistributive power of the central government (Macdougall 1977; Mélitz and Zumer 1998; Barberán et al. 2000).

Does federalism encourage inequality? Or, do central government transfers help subnational governments provide useful services and reduce inequality? Is there variation among federal cases in their capacity to diminish inequality? Are federal countries more capable to reduce inequality than unitary cases?

Using descriptive statistics and regression models for original panel data from Argentina, Brazil, Chile, Colombia, and Mexico, between 1983 and 2013 , this study empirically analyses whether transfers from the central government to subnational units reduce or worsen interregional and interpersonal inequality. Some of the selected cases are decentralized federal systems (Argentina and Brazil), others are more or less centralized federations (Mexico), more or less decentralized unitary regimes (Colombia), or centralized unitary cases (Chile). Out of these differences, this study examines whether variation in the institutional structures and criteria for the territorial distribution of fiscal resources for these five cases influence interregional and interpersonal equity. 
The article, first, discusses the literature on the topic. It presents the main theoretical claims in the second part. Third, it describes the data and identifies the methodological strategy. In the fourth section, it presents and discusses the empirical results and explores their comparative implications in the conclusion.

\section{Does federalism mean inequality?}

Federalism is blamed for producing several socioeconomic and political distortions, ranging from inequality (Lowi 1984, 379; Wildavsky 1984, 68; Rodden 2009, 2-3; see Beramendi 2012, 4 for a review), fiscal deficits (Rodden and Wibbels 2002; Wibbels 2005; Rodden 2006), patronage and clientelism (Samuels 2003; Wibbels 2005; Remmer 2007; Ardanaz, Leiras, and Tommasi 2012), the creation and maintenance of political machines that lead to 'quasi-feudal' domination (Ardanaz, Leiras, and Tommasi 2012, 17), limited political competition, executive dominance (Abrucio 1998; Samuels and Abrucio 1997), and the emergence and survival of subnational political dynasties or simply dictatorships (Gibson 2005; Gervasoni 2010).

For these authors, the abovementioned socioeconomic and political distortions are the consequences of, at least, three main mechanisms. ${ }^{2}$ The first one is the vertical imbalance federal systems produce between the revenues subnational units collect and the spending they undertake. The federal government usually fills up this vertical imbalance with federal transfers or fiscal bailouts. For part of the literature, the vertical imbalance creates an incentive for subnational politicians to overspend. In the end, the federal government usually rescues fiscally irresponsible states (Rodden and Wibbels 2002; Wibbels 2005; Rodden 2006). Subnational overspending affects the federal government, increasing its fiscal deficit and generating inflation and debt. These fiscal disequilibria limit the capacity of the central administration to implement efficient policies that improve social indicators nationally.

The second mechanism is legislative overrepresentation. Bennett and Mayberry (1979) and Holcombe and Zardkoohi (1981) developed early studies claiming that overrepresented states tend to receive more federal grants per capita. Part of the comparative literature on the topic reached similar conclusions (see Gibson and Calvo 2000; Samuels and Snyder 2001; inter alia). The main reason is that the political benefits from a marginal dollar of increased grants to a small and overrepresented state are greater than a marginal dollar of increased grants to a large state in which the per capita impact is smaller. As a result, federal governments need those provinces or states to put together a governing coalition in Congress. If more overrepresented provinces tend to receive more transfers, the effect at the subnational level is more patronage and clientelism and, hence, stronger subnational political machines. The effect at the federal level is that federal resources are mostly 
channeled to build up political coalitions with overrepresented provinces in Congress and not to forge nationwide programmatic policies from the central administration (Ardanaz, Leiras, and Tommasi 2012). The main policy implication of these distortions is that non-programmatic spending has limited or negative effect in improving socio-economic indicators and reducing inequality.

The third mechanism is rentierism. Federal transfers work as a rent subnational units receive from the central government (Gervasoni 2010). Rentier governments spend monies from transfers, some authors claim, in expanding their political machines through patronage and clientelism to buy off political loyalties as well as in enlarging their repressive apparatus to suppress discontent and remain in power (Gervasoni 2010; Ardanaz, Leiras, and Tommasi 2012). States' reliance on federal transfers produces a decline in taxes, which in turn produces a reduction in popular pressures for government accountability. One of the most important causal connectors between federal transfers, quasi-feudal domination, the emergence and survival of political dynasties and authoritarian rule is the way in which governments spend these rents from the federal government. Provinces, particularly in Argentina, use federal transfers to finance more public employment, patronage, and clientelism, discouraging private activity and productivity because the public sector pays a wage premium relative to the private sector (Capello et al. 2009). This, in turn, worsens social indicators and the capacity of the federal government to improve them.

At the theoretical level, several scholars challenge previous claims, arguing that federalism can improve aggregate and subnational economic outcomes instead of generating fiscal disequilibria, for instance through competition among states that can help preserving markets (Tiebout 1956; Weingast 1995). Federalism can also contribute to a 'gentler and kindler' democracy by encouraging political negotiations and consensus building among several actors (Lijphart 2012). In political terms, federalism can actually represent a limit to excessive central power (Elazar 1991) by creating veto points (Tsebelis 2002; Stepan 2005), instead of helping create subnational feuds.

Some scholars reverse the line of causality presented in previous studies: for these authors, the territorial distribution of income is what shapes the constitutional decisions and institutional designs in federal agreements (Bolton and Roland 1997; Alesina and Spolaore 2003; Wibbels 2005; Beramendi and Díaz-Cayeros 2008; Beramendi 2012). And still others, present a conditional relationship. Beramendi (2012), for instance, explains the origins of different fiscal regimes in federations, arguing that the impact of federalism on various forms of inequality is conditional on the nature of the system of representation and the very origins of the federal fiscal contract. 
Despite these lively theoretical debates, recent empirical research seems to reach inconclusive conclusions in relation to the socio-economic impact of federal transfers. This is the case, for example, of the literature that analyses the effects of federal transfers in regional economic convergence (usually measured using per capita income). Some studies find a positive relationship between transfers and economic convergence (Coulombe and Lee 1995; Cappelen et al. 2003; Kaufman, Swagel, and Dunaway 2003; Rangarajan and Srivastava 2004; De Oliveira 2008; Maciel, Andrade, and Kuhl 2008). Others conclude that this relationship is not statistically significant, even for some of the same cases (Ramakrishnan and Cerisola 2004; Rodríguez 2006). A third group of studies holds that the relationship is negative (Bagchi 2003; Martinez-Vazquez and Timofeev 2010).

While the literature on economic convergence has created an important empirical discussion, Díaz-Cayeros $(2004,664,667)$ contends that the redistributive consequences of federal transfer systems have been largely ignored in most academic debates on federalism. And many scholars who empirically analyse variations in the redistributive impact of federal transfers, focus exclusively in developed countries (Macdougall 1977; Mélitz and Zumer 1998; Barberán et al. 2000). ${ }^{3}$ Moreover, most of these studies do not try to explain the impact of transfer systems across cases and over time. ${ }^{4}$

This research works in line with other studies that have empirically analysed the socio-economic and redistributive effects of transfers from the central government (Rao and Singh 2001; Treisman 2007; Beramendi 2008; Beramendi and Díaz-Cayeros 2008; Rodden 2009; Beramendi, Díaz-Cayeros, and Rogers 2017). It first presents an index that empirically describes how redistributive central governments' transfers are across the selected cases and time. It then seeks to empirically assess whether larger amounts of total transfers from the central government to all subnational units (defined as a larger redistributive capacity of the central government) are associated with more equity, controlling for fiscal deficits, overrepresentation, and other key variables in the literature.

\section{Progressive federalism and inequality}

This study, along with several others for more developed democracies, contends that federal transfers systems vary in the levels of redistribution they achieve. It claims that more progressive federal transfers systems may help reducing inequality both among and within provinces. More progressive federal transfers systems are those that collect revenue from richer regions of the country and redistribute it to poorer areas. More regressive federal transfer systems, on the contrary, are those which do not redistribute revenue from richer to poorer regions, basically because they guarantee that richer provinces can collect the lion's share of revenue from their 
own territories. More regressive federal transfer systems should generate more concentration of income in richer provinces and have less capacity to help poorer provinces to reduce inequality within their boundaries.

This study measures the redistributive capacity of the central government and explores whether more progressive federal transfer systems are associated with a reduction in interregional inequality (i.e. inequality among provinces) and interpersonal inequality (i.e. inequality among individuals within each province).

Several authors claim that federal transfers generate socioeconomic and political distortions at the subnational (and national) level. Federal transfers tend to incentivize provincial overspending and help generate large fiscal deficits (both at the provincial and national levels). They also contribute to consolidate and expand incumbents' political machines, increasing clientelism and patronage to buy political loyalties as well as enable repression to control political dissent in the provinces. Facing weak (or inexistent) social accountability, transfers may also foster corruption and facilitate the personal enrichment of those in power in the provinces. If this is the case, federal transfers should end up generating more income for those in government and those politically (and personally) related to them. On top of that, by increasing patronage and clientelism, federal transfers may also reduce private employment and productivity (Capello et al. 2009).

The main policy implication is that fiscal mismanagement, clientelism, patronage, and corruption should have limited or negative effects in improving provincial socio-economic indicators. This would be particularly the case in more backward provinces, which tend to have worse social indicators and receive more federal transfers per capita than the national average. Poorer provinces, this argument goes, would see their political elites getting richer, their political supporters receiving some of the spoils, while the majority of the population in need would have to face more hardships as a result of bad economic and social policies. Without sound social policies, poverty and unemployment would increase and access to basic social services would worsen.

If the majority of the population in backward provinces get poorer as a result of bad economic and social policies, inequality in these provinces should increase. If more transfers also encourage more profits for incumbents, their clique, and close supporters, this should also help increasing interpersonal inequality in the province.

But another crucial implication of these claims is that progressive federal systems also promote more inequality among provinces. While these progressive transfer systems should be, in principle and by definition, redistributive, in reality, they work in the opposite direction. First of all, these transfer systems soak well-off provinces (those which also tend to have more political competition, more private employment, better policies, and lower corruption), depleting their revenues and limiting their capacity to cope with their own 
social needs (many of them generated by migrant families coming from poorer regions of the country - or from other countries). The heavy tax burden these transfer systems pose also discourages economic and productive activities in these provinces. Paradoxically, more progressive federal systems tend to impoverish richer provinces (especially those more populated, such as the provinces of Buenos Aires, Córdoba, and Santa Fe in Argentina or São Paulo and Minas Gerais in Brazil), while creating feuds of rich political elites and associated political supporters in those provinces receiving more federal transfers, which are usually the less populated and more politically overrepresented (and not always the poorest). This generates a race to the bottom and increases inequality among provinces (and not only within them). For this 'regressive' view of federalism, federal countries would be better off without distortive transfers systems.

However, for a different perspective, called here 'progressive', federal transfer systems may contribute to reduce interregional and interpersonal inequality. Several key social services, such as primary health and education, are policy responsibilities of subnational units in most decentralized federal systems, including several cases in our sample (e.g. Argentina, Brazil, and Mexico) and even in some decentralized unitary countries (such as Colombia). Policy responsibilities of subnational units dramatically increased after the 1990s decentralization policies and the retrenchment of national governments (and the social services they delivered) in the midst of adjustment reforms. These decentralized social services are crucial to improve socio-economic indicators at the subnational level. Without transfers to subnational governments, more disadvantaged provinces depend on their own revenue to deliver vital social services. This severely diminishes their capacity to deal with the social problems they face, especially because their own revenue is lower than the national average and they usually have to deal with worse social indicators (and in most cases, they have poorly trained professionals with low salaries to deliver them).

If more deprived subnational units receive more federal transfers and allocate a larger share of their budgets (comprising federal transfers and their own revenue) to social spending (instead of increasing clientelism and patronage), social indicators in these provinces would tend to improve. If that is the case, then we could expect a reduction in provincial interpersonal inequality. If less well-off provinces improve their social indicators, progressive federal transfer systems may also help reducing inequality between them and those that are richer.

\section{Variables and data}

The main independent variable is the redistributive capacity of central government $(\mathrm{RC} \mathrm{cg})$, which was calculated following a literature on the topic for 
central countries (since the MacDougall Report 1977; see also Mélitz and Zumer 1998; Barberán et al. 2000) that has not been applied, as far as we know, in Latin America. The RCcg is the central government's fiscal ability to reduce regional disparities and measures the percentage change in a Gini coefficient before and after transfers. More precisely, to obtain it, this work calculated:

(i) The initial per capita revenue of subnational units, which is their own revenue or the revenue they collect. $^{5}$

(ii) The final per capita revenue of subnational units, which is their total revenue, or the sum of their initial own revenue per capita and the central government's per capita transfers ${ }^{6}$ (for details, see Appendix).

(iii) The Gini coefficient for the subnational units' initial revenue and their final revenue, for each country and year of the time series.

(iv) The redistributive capacity, which was obtained by subtracting the final revenue Gini coefficient to the initial revenue Gini coefficient. More progressive federal transfers systems have a positive value in the index of redistributive capacity of the central government; more regressive federal transfers systems have a negative value in it.

The main goal behind the selection of this variable is to explore whether more progressive federal transfer systems (i.e. higher redistributive capacity of central government) are empirically associated with lower inequality. However, the article will also test the more general claim that federal transfers (reported in USD per capita) help to reduce (or to increase) inequality. This variable will assess whether central government transfers generate distortions and bad subnational policies, or help provincial and state governments to reduce inequality by providing better social services.

The main dependent variables are interregional and interpersonal inequality. The former is measured by the Gini Index of Interregional Inequality (GINlir). The GINlir measures the income gap of the average per capita Gross Geographic Product (GGP) for each province, state or department with respect to the national average. According to usual standards, provincial GGP measures the value of the total final goods and services produced in a province or state in a given year. ${ }^{7}$ Very importantly, central government transfers to subnational units are not included in the calculus of GGP. Hence, this study explores whether federal transfers are empirically associated with more or less equality among provinces in their GGP, or the average production of goods and services. A GINlir of 1 indicates perfect inequality, or a theoretical situation where a province has all the GGP in a country and the rest of the districts have nothing. A GINlir of 0 indicates perfect equality, or a situation in which all provinces have the same average GGP. 
It is possible to calculate the Gini within each district, with average incomes for each individual or household or a sample of them for each district. Household surveys are required for this purpose. Interpersonal Inequality (GINlip) is measured using a Gini index for each province or state average individual income per capita, calculated out of survey data from official sources for each country (See Appendix).

The study explores the effect of federal transfers as well as per capita provincial social spending on provincial interpersonal inequality. Provincial social spending is reported as the total per capita amount in USD of the provincial budget allocated to social areas, including health, education, social programmes, and social infrastructure (reported from official sources for each country; See Appendix).

It also includes a series of control variables. First, it explores whether legislative overrepresentation and fiscal deficits impact positively on inequality, as several authors in the literature would expect. Overrepresentation is calculated based on the Loosemore-Hanby index of electoral disproportionality (as Samuels and Snyder 2001 do): Overrepresentation $=|s i-v i|$, where si is the percentage of all seats allocated to district $i$, and $v i$ is the percentage of the overall population residing in district $I$. Fiscal deficits are the balances of government operations (economic classification), as a percentage of GDP (reported by ECLAC-CEPALSTAT). Second, it examines whether inequality varies depending on structural controls, such as national economic growth and state population (See Appendix for data sources).

\section{Case selection and analysis}

The database assembles observations for the abovementioned variables for the provinces or states of the main federations in the region, Argentina, Brazil and Mexico, and the regions and departments of two unitary cases, Chile and Colombia. These cases were selected because they show the largest possible variation in all key variables over time in Latin America, particularly in terms of the institutional structure of the state: decentralized federal (Argentina and Brazil), more or less centralized federal (Mexico), more or less decentralized unitary (Colombia), and centralized unitary cases (Chile). The cases were also selected because there are comparable data available for all of them. Other cases were not included because of serious problems in data availability, particularly in the case of the only Latin American missing federation in the study, Venezuela. In all cases, the study analyses the period before and after the fiscal and administrative decentralization processes of the late 1980s and early 1990s. The years for each of the variables range between 1983 and 2013, depending on the country of study and the type of variable (See Appendix).

With these data, this article first reports basic descriptive statistics for the main independent and dependent variables. Then, it calculates simple 
correlations between the key variables. Finally, it presents a regression analysis. ${ }^{8}$ As a consequence of to the panel structure of the data, some assumptions of the linear regression model (OLS) are problematic, especially the independence of observations and errors, as well as the equal variance for the errors for all observations. The Breusch-Pagan/Cook-Weisberg test and a scatterplot for the error term in the main models indicate that there is heteroskedasticity in it. The Wooldridge test reports autocorrelation in the panel data. Moreover, the Hausman test of random versus fixed effects reports a very low $p$-value for the model using random and fixed effects $(p=.0000)$. Therefore, it is advised to use a fixed effects regression model. A conventional way to deal with these problems would be using ordinary least squares regression with panel corrected standard errors (PCSE, Beck and Katz 1995), to compute the variance-covariance estimates and the standard errors assuming that the disturbances are heteroskedastic and correlated across panels. The study also compares the robustness of the PCSE results with a GLS model with fixed effects for districts and years. The results of the PCSE and GLS models are reported in Table 3 and discussed in the Section on Regression Analysis.

Due to the hierarchical structure of the data, one must also account for correlation of the outcome and the error term within states/provinces in a given year. Including dummies for each subnational unit in the dataset reduces parsimony and may generate unnecessary noise and ignore the random variability associated with group-level characteristics (Luke 2004, 7). In order to address these limitations and control the robustness of the results in the previous models, the study also reports a multilevel model, which are used when data are collected in units (provinces and states) nested in clusters (countries). This model tries to account for changes in an outcome (interpersonal inequality) on the basis of variables measured at both the provincial level (or level 1, e.g. provincial spending, GDP, population), and the country level (the group level or level 2, e.g. RCcg, economic growth). As a final robustness check, the article also includes a Prais-Winsten $A R(1)$ regression to control for first-order autocorrelation.

\section{Descriptive statistics}

\section{Interregional inequality}

In absolute values, Argentina stands out as the most unequal country interregionally (the average interregional Gini (GINlir) for the series is $0.33)$, followed by Brazil (0.30), Colombia (0.28), Mexico (0.24), and Chile (0.24; Figure 1). The two most interregionally unequal are federal countries, Argentina and Brazil, but Mexico is less unequal than Colombia (Table 1 and Figure 1). 


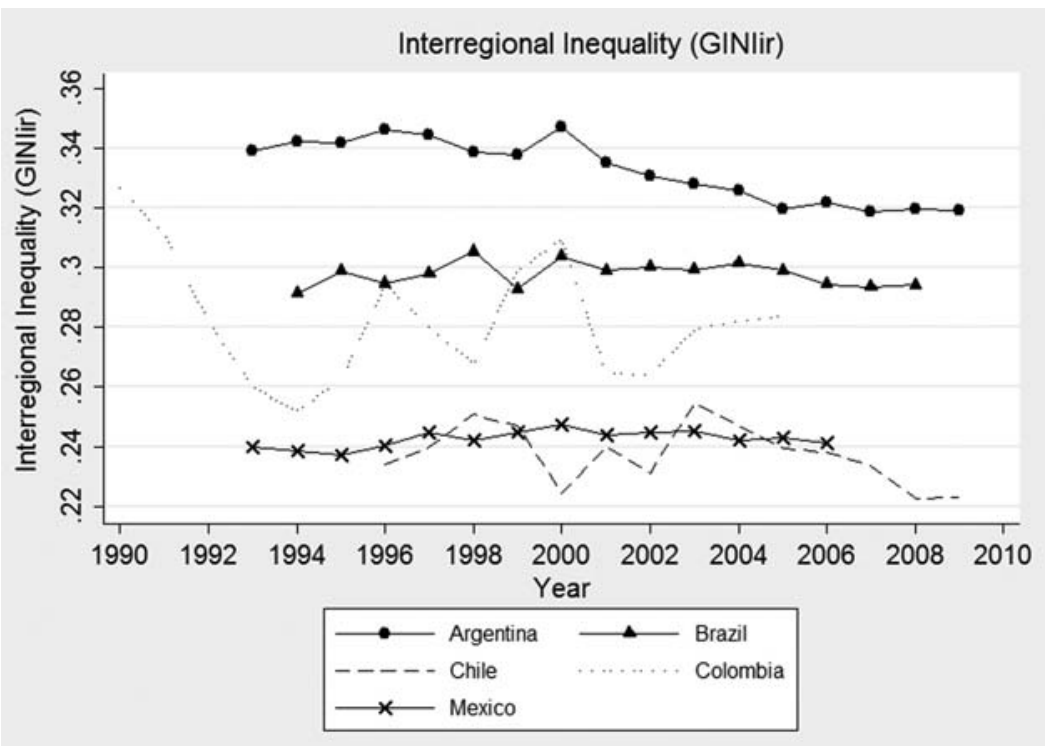

Figure 1. Interregional inequality (GINlir).

\section{Interpersonal inequality}

Brazil has the highest average state interpersonal inequality of the selected cases, with an average Gini for the series of 0.56. Argentina has the lowest, 0.44. Mexico and Argentina are the least unequal according to this measure, and they are federal countries. Brazil is very unequal in this regard, but Colombia and Chile too (Figure 2). In sum, these measures of interregional and interpersonal inequality report variation among federal and unitary cases. The claim that federal countries tend to be more unequal than unitary cases requires some empirical precision.

\section{Redistributive capacity of the central government}

The index reveals that Argentina has the largest redistributive capacity of the selected cases for the last year available in the series (22\% in 2013), followed by Mexico ( $16 \%$ in 2007). Brazil is the least redistributive federation, with $5 \%$ in 2006; followed by Chile ( $6 \%$ in 2010) and Colombia ( $9 \%$ in the same year).

Table 1. Interregional inequality and redistribution.

\begin{tabular}{lcc}
\hline & $\begin{array}{c}\text { High redistributive capacity } \\
\text { of the Central Government }\end{array}$ & $\begin{array}{c}\text { Low redistributive capacity } \\
\text { of the Central Government }\end{array}$ \\
\hline $\begin{array}{l}\text { High interregional inequality } \\
\text { (GINlir) }\end{array}$ & Argentina & $\begin{array}{c}\text { Brazil } \\
\text { Colombia } \\
\text { Low interregional inequality } \\
\text { (GINlir) }\end{array}$ \\
\hline
\end{tabular}




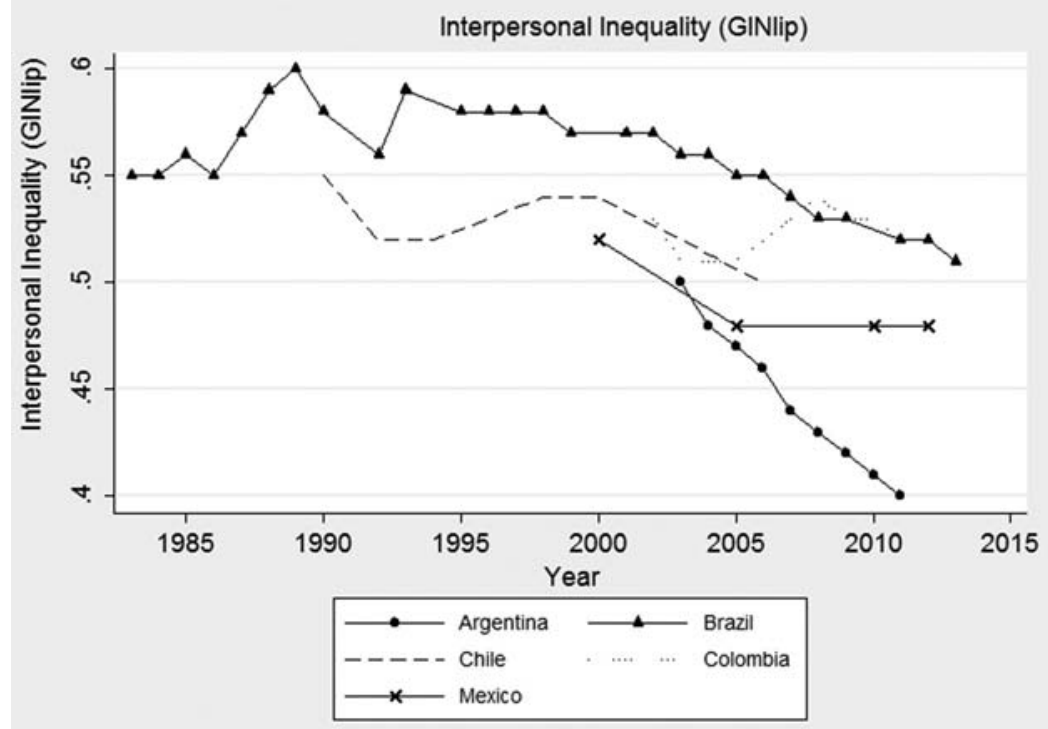

Figure 2. Interpersonal inequality (GINlip).

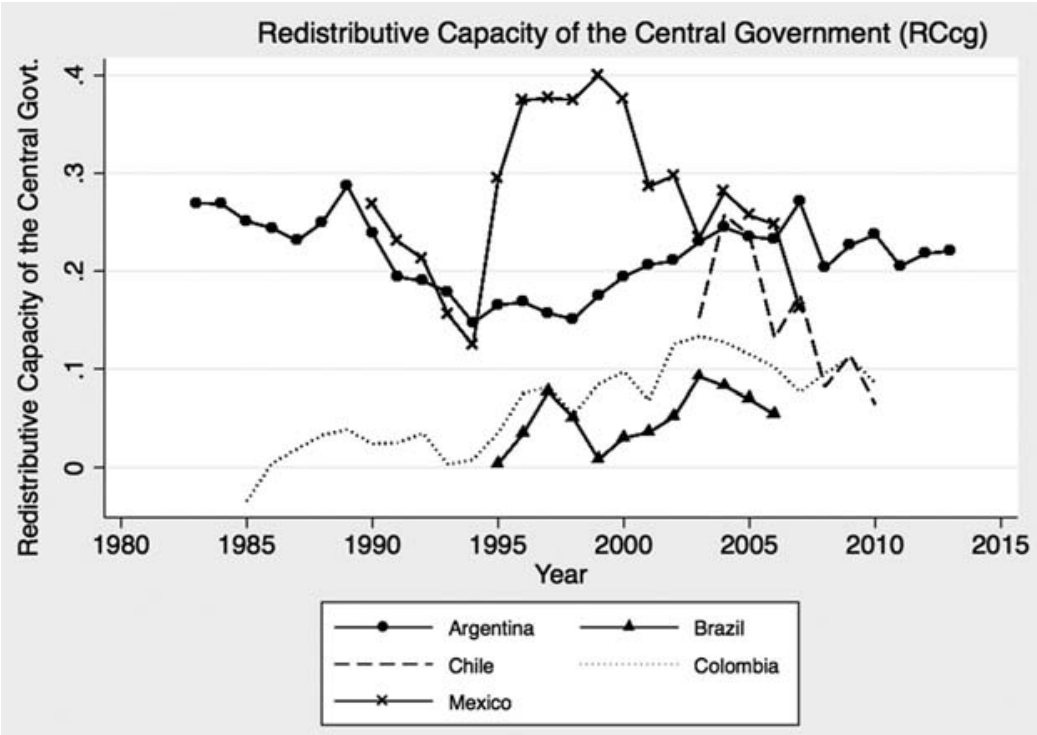

Figure 3. Redistributive capacity of the central government (RCcg).

These data indicate that federations redistribute almost double the unitary cases: the average for the three federations in this study is $14.52 \%$; for unitary countries is $7.47 \%$ (Figure 3 ). 
Table 2. Interpersonal inequality and redistribution.

\begin{tabular}{|c|c|c|}
\hline & $\begin{array}{l}\text { High redistributive capacity } \\
\text { of the Central Government }\end{array}$ & $\begin{array}{l}\text { Low redistributive capacity } \\
\text { of the Central Government }\end{array}$ \\
\hline $\begin{array}{l}\text { High interpersonal inequality } \\
\text { (GINlip) }\end{array}$ & - & $\begin{array}{c}\text { Brazil } \\
\text { Chile } \\
\text { Colombia }\end{array}$ \\
\hline $\begin{array}{l}\text { Low interpersonal inequality } \\
\text { (GINlip) }\end{array}$ & $\begin{array}{l}\text { Argentina } \\
\text { Mexico }\end{array}$ & - \\
\hline
\end{tabular}

Out of the analysed cases, Argentina stands out as the most redistributive country (it has the highest RCcg), and although it has reduced interregional inequality, still remains as the most unequal in this measure. Chile, on the contrary, has a low redistributive capacity of the central government, low interregional inequality, but high interpersonal inequality. The other three countries are intermediate cases in relation to these two cases (Table 1).

In relation to interpersonal inequality, the five cases can be placed in two cells: two of them show high redistributive capacity of the central government and low interpersonal inequality (Argentina and Mexico), while the three others cluster around low values of redistributive capacity of the central government and high values of interpersonal inequality (Brazil, Chile, and Colombia) (Table 2). Argentina and Chile show opposite positions in the two tables.

\section{Correlation analysis}

The results of the bi-variate correlation analysis indicate that, in general, the redistributive capacity of the central government is statistically associated with reductions in interregional inequality, as expected. The Pearson's $R$ between redistributive capacity of the central government (RCcg) and interregional inequality (GINlir) is relatively robust, negative $(-0.3)$, and statistically significant. The Pearson's R between RCcg and interpersonal inequality (GINlip) is even more robust, negative $(-0.63)$, and also statistically significant.

Results show variation in the correlations among cases. In Argentina, the correlation between RCcg and GINlir is more robust than for all cases, negative (-0.84), and statistically significant. This coefficient is statistically insignificant in one case (Colombia), and positive and significant for the others. These mixed correlation results across cases can also be observed between RCcg and GINlip. According to these pairwise correlations, there seems to be empirical support for all the countries together but only some cases show the expected negative relationship between the two variables. Further research is needed to account for specific cases that seem to deviate from the general pattern, particularly Mexico, where more federal transfers do not appear to be associated with less inequality. Further research could also explore whether these results hold when including 
other important missing cases in this sample, such as Bolivia, Ecuador, Peru, or Venezuela.

\section{Regression analysis}

The regression results assessing the relationship between the redistributive capacity of the central government and interpersonal inequality ${ }^{9}$ support some of our expectations and are in line with the correlation analysis for all cases (see Table 3). They indicate that a larger redistributive capacity of the central government is empirically associated with reductions in interpersonal inequality, or that more progressive federal transfer systems are empirically related to lower inequality. Controlling for changes in third variables, an increase of one point in the redistributive capacity of the central government is related to a reduction in the GINlip index by 0.23 in Model 1. Put in another way, a change equivalent to one standard deviation in RCcg is associated with a 2.3 change in GINlip, which represents one-third of this variable's standard deviation. This coefficient is statistically significant, although close to the limit of the usually accepted values of statistical significance in Model 1. In Models 2 (GLS with fixed effects) and 3 (Multilevel), the coefficient is even more robust

Table 3. Regression results.

\begin{tabular}{|c|c|c|c|}
\hline Variables/model & $\begin{array}{l}\text { Model 1: } \\
\text { PCSE }\end{array}$ & $\begin{array}{l}\text { Model 2: GLS } \\
\text { (Fixed Effects) }\end{array}$ & $\begin{array}{l}\text { Model 3: } \\
\text { Multilevel }\end{array}$ \\
\hline Redistributive capacity of the Central Government & $\begin{array}{r}-0.2254^{*} \\
(0.1272)\end{array}$ & $\begin{array}{c}-0.7901^{* *} \\
(0.3116)\end{array}$ & $\begin{array}{c}-0.6719^{* * *} \\
(0.0732)\end{array}$ \\
\hline Subnational Social Spending (USD per capita) & $\begin{array}{c}-0.0013^{* * *} \\
(0.0002)\end{array}$ & $\begin{array}{c}-0.0010^{* *} \\
(0.0002)\end{array}$ & $\begin{array}{c}-0.0007^{* *} \\
(0.0003)\end{array}$ \\
\hline Overrepresentation & $\begin{array}{l}0.5107^{* * *} \\
(0.1797)\end{array}$ & $\begin{array}{c}-0.1688 \\
(0.2613)\end{array}$ & $\begin{array}{c}-0.1387^{* * *} \\
(0.0398)\end{array}$ \\
\hline Fiscal imbalance & $\begin{array}{c}0.2701 \\
(0.3200)\end{array}$ & $\begin{array}{l}1.8241^{* * *} \\
(0.3389)\end{array}$ & $\begin{array}{l}1.6354^{* * *} \\
(0.1332)\end{array}$ \\
\hline Economic growth & $\begin{array}{c}-0.4548 \\
(0.2950)\end{array}$ & $\begin{array}{c}0.2478 \\
(0.3392)\end{array}$ & $\begin{array}{c}-0.5403^{* * *} \\
(0.1401)\end{array}$ \\
\hline State population & $\begin{array}{c}0.0000^{*} \\
(0.0000)\end{array}$ & $\begin{array}{c}0.0000 \\
(0.0000)\end{array}$ & $\begin{array}{c}-0.0000^{* * *} \\
(0.0000)\end{array}$ \\
\hline Argentina & & - & \\
\hline Brazil & & $\begin{array}{c}3.0504 \\
(5.4019)\end{array}$ & \\
\hline Chile & & Dropped & \\
\hline Colombia & & $\begin{array}{c}4.2047 \\
(3.7538)\end{array}$ & \\
\hline Mexico & & $\begin{array}{l}6.5216^{* * *} \\
(1.9553)\end{array}$ & \\
\hline Year dummies & & $\begin{array}{l}\text { Omitted } \\
\text { (to save space) }\end{array}$ & $\begin{array}{c}\text { Omitted } \\
\text { (to save space) }\end{array}$ \\
\hline Constant & $\begin{array}{l}58.5957^{* * *} \\
(2.1113)\end{array}$ & $\begin{array}{l}64.4868^{* * *} \\
(8.4555)\end{array}$ & $\begin{array}{l}69.2149^{* * *} \\
(0.8975)\end{array}$ \\
\hline$R$-squared & 0.4666 & 0.6093 & $\mathrm{n} / \mathrm{a}$ \\
\hline Number of cases & 551 & 551 & 551 \\
\hline
\end{tabular}


( -0.79 and -0.67 respectively) and statistically significant. The standard error in the multilevel model is the lowest and largest in the GLS, probably indicating that dummy variables may generate more noise in the latter, and that the former deals better with the group-level variability. As a further robustness check, a Prais-Winsten $A R(1)$ regression also reports very similar results (see Table A3, in the Appendix).

In order to check the consistency of results, and to assess the more general claim that federal transfers help reducing (or increasing) inequality, the article also tests the effects of federal transfers (in USD per capita) on interpersonal inequality. Results indicate that a one USD increase in per capita federal transfers is related to a .0011 reduction in the interpersonal Gini index. Put in another way, a $\$ 1000$ increase in per capita federal transfers (the standard deviation is $\$ 612$ per capita) is associated with a 1.1 point reduction in GINlip. The coefficients in the three models are almost identical and statistically significant (these results are reported in Table $A 2$, in the Appendix, due to limitations in space).

In relation to subnational social spending, results indicate that a one USD increase in per capita provincial spending is statistically linked to a .0013 reduction in the Gini index that measures inequality within the province. In other words, an increase in $\$ 1000$ per capita social spending (the standard deviation is \$823) is reflected in a reduction in GINlip of 1.3 , which is also a considerable value. The coefficients in the three models (and in AR1) are quite similar and statistically significant in all of them.

These results seem to indicate that, in general, more federal redistribution is associated with reductions in provincial interpersonal inequality. Ceteris paribus, then, they appear to at least partially contradict the 'conservative' perspective for which federal transfers result in bad social policy outcomes. And they offer some support for the claims of a more 'progressive' perspective, in which provinces may use federal transfers to encourage the performance of decentralized social services and improve social indicators, especially for the less well-off sectors of the population. This is reinforced when subnational units allocate a larger share of their budgets into social spending, particularly in poor regions, where the marginal impact of a dollar is greater because there are more needs. This view does not intend to negate the existence of clientelism and patronage in provincial politics. It only brings some empirical evidence on a connection between federal transfers and reductions in inequality and a plausible theoretical argument linking them.

Results do not seem to allow firm conclusions regarding the role of overrepresentation. In Model 1, this variable is empirically associated with more interpersonal inequality, probably indicating that more overrepresented states tend to be also more unequal. But the coefficient is negative and significant in Model 3, while it does not reach the standards of statistical significance in Model 2. When controlling for the main variables in the model, these 
inconsistent findings seem to be contrary to the view that overrepresentation generates non-programmatic spending and negative aggregate policy results. All in all, future research may further refine the controls in the models and study the conditional effect of overrepresentation over interpersonal inequality, interacting it, for instance, with different types of subnational spending. This may help us have more solid conclusions in relation to whether more federal funds allocated to more overrepresented states imply worse policy outcomes.

The coefficients for provincial population also reveal inconclusive results in the different model specifications. The one in Model 1 is positive and statistically significant, probably indicating that more populated districts are also those that are more unequal. But it is negative in Model 3 and it loses significance in Model 2, when district and year specific characteristics are incorporated into the model through dummy variables.

In relation to the economic controls, fiscal imbalances are empirically related to increases in interpersonal inequality in the last two models, but the coefficient is not statistically significant in Model 1 . The coefficients for yearly economic growth rates do not reach the usual minimum levels of statistical significance in the first two models. But it is negative and significant in Model 3. These results encourage further research on the provincial and national economic conditions that may reduce or increase inequality in the provinces.

National dummy variables in Model 2 have positive coefficients, indicating that Brazil, Colombia, and Mexico have larger values of GINlip when compared to the reference category (Argentina; Chile is dropped from the regression). However, only the difference between Mexico and Argentina is statistically significant. This is further indication that, despite the overall results and some clear national trends (particularly for Argentina), more research is needed to account for differences in specific cases, particularly Mexico.

All variables account for about $47 \%$ of the variation in the dependent variable in Model 1 and about $61 \%$ in Model 2, when the dummies are included into the estimation.

\section{Final comments}

Inequality among provinces and individuals in Latin America is a scandal (paraphrasing what O'Donnell (1996) wrote on the social situation in this region more than two decades ago). Despite recent improvements, both the federal and unitary cases analysed in this work still show very high levels of inequality.

This study empirically reports variation in inequality among federal and unitary cases and within them across time. Some unitary cases are more unequal interregionally than federal countries (e.g. Colombia in relation to Mexico). And some unitary cases also exhibit higher interpersonal inequality 
than some Latin American federations (e.g. Chile in relation to Argentina and Mexico). These results suggest that federalism does not necessarily, and always, mean higher inequality than unitary cases.

Furthermore, one of the main differences between federal and unitary cases is that the former have mechanisms that appear, according to the results in this study, to be associated with reductions in inequality among and within districts. These instruments were created out of the political activation (and coordination) among the least developed provinces or states of the federation, which agreed to be part of it in exchange for politico-institutional (i.e. overrepresentation) and fiscal (i.e. federal transfers) devices that could favour them in the future. Some of these mechanisms, particularly progressive federal transfer systems, seem to fulfil, at least partially, this role. When provinces spend a larger share of their budget in social services appears also to be crucial to reduce inequality, helping to strengthen the redistributive effect of progressive federal transfers.

The main goal of this article was to explore whether it was possible to identify a general pattern of association between progressive central government redistribution and inequality. Further research may contribute to the results found here by exploring particular deviations from this general pattern, somewhat clear in the case of Mexico, as well as by including other federal and unitary cases in the region and beyond it, to understand in more detail the causal links between redistributive federal transfers and inequality.

\section{Notes}

1. Differences in income can also be observed within provinces or states and even within the municipalities. However, this work focuses exclusively on the intermediate level of government (provinces, states, or departments). For simplicity reasons, it uses the term provinces to also refer to states or departments.

2. Smith and Revell $(2016,245)$ underline the role of other mechanisms. For them, idiosyncratic micro-incentives rather than institutions contribute to shift resources between the federal and subnational units to satisfy local client groups and advance individual careers in Mexico and Argentina.

3. Most of these studies analyse the redistributive power of the central government, estimated by the elasticity coefficients of regional income and expenses in relation to its initial income, or the income that existed before the intervention of the public sector.

4. Rodden $(2004,2009)$ is a partial exception to this, but his work analyzes only two cases in the region, Argentina and Brazil, in relation to other cases in other regions.

5. Most of the literature on the redistributive power of the central government in developed countries use the states' per capita GDP as the primary measure of the states' initial income (see Rodden 2009,6 ). This study uses the subnational units' own revenue as their initial income in order to avoid endogeneity. This is a better measure because in some states or provinces, particularly the poorest and the most dependent on federal transfers, a large proportion of their GDP depends on federal transfers. 
6. Federal transfers are centrally managed funds, either collected by the central government or by subnational units, which are transferred by the national treasury to subnational units (both intermediate and local). Usually, part of these transfers is regulated by special laws that determine the total share to be allocated to subnational units and how this share is distributed to each district (the revenue sharing regime (coparticipación) in Argentina, the participation funds (fundos de participação) to states and municipalities in Brazil, the participaciones in México, or the situado fiscal in Colombia). Another part of these transfers is usually distributed discretionarily, because no specific law determines which district should receive a particular grant (although specific laws establish the total amount that can be transferred discretionarily), such as the Contributions from the National Treasury in Argentina or voluntary transfers in Brazil (Bonvecchi and Lodola 2011). Federal transfers to subnational units may be earmarked: subnational units are compelled to spend them in certain areas, such as the National Housing Fund in Argentina (FONAVI), the Education and Health Funds in Brazil (FUNDEF and SUS), or the social infrastructure fund (SIF) in Mexico (Hernández-Trillo 2016, 4); but there are other transfers which subnational units can spend without restrictions. Federal transfers in this work include total transfers (also reported as capital and current transfers) for each district (see Appendix for more details).

7. According to the definition of the US Bureau of Economic Analysis. See: https:// www.bea.gov/newsreleases/regional/gdp_state/qgdpstate_newsrelease.htm

8. Due to the limited number of observations $(N=64)$, the study presents a correlation analysis between $\mathrm{RCcg}$ and GINlir. For this reason, regression results between these variables are not reported in the Table.

9. As indicated, regression results between RCcg and GINlir are not reported due to the low number of observations. The coefficient for $\mathrm{RCcg}$ in the main regression model is negative, relatively robust $(-.1)$, and statistically significant $(p=.026)$. However, these results should be taken with care since the number of observations is very low.

\section{Disclosure statement}

No potential conflict of interest was reported by the author.

\section{Funding}

This work was supported by the National Council for Scientific and Technical Research (CONICET) and the Carolina Foundation and its Center for Latin American Studies and International Cooperation (CEALCI). Santiago Alles, Ana Bovino, Belén Cáceres, Noelia Carmona, Ignacio Mamone, Julia Rubio, and Dominica Zabala provided research assistance at different stages for this work. A previous version of the manuscript was presented at the workshop on "Fiscal Federalism, Social Policy, and Subnational Politics in South Asia and Latin America," at King's College, London, May 19-20, 2016. The author is grateful for the comments and suggestions of those attending the workshop as well as those from the editors and the anonymous reviewers of Regional \& Federal Studies. Any remaining error is the sole responsibility of the author. 


\section{References}

Abrucio, F. 1998. Os Barões da Federação: Os Governadores e a Redemocratização Brasileira. São Paulo: Coleção Comentário, Universidade de São Paulo.

Alesina, A., and E. Spolaore. 2003. The Size of Nations. Cambridge: Cambridge University Press.

Ardanaz, M., M. Leiras, and M. Tommasi. 2012. The Politics of Federalism in Argentina: Implications for Governance and Accountability. IDB Working Paper No. IDB-WP-327.

Bagchi, Amaresh. 2003. Fifty Years of Fiscal Federalism in India: An Appraisal. Working Papers 03/2. National Institute of Public Finance and Policy.

Barberán, R., N. Bosch, A. Castells, and M. Espasa. 2000. The Redistributive Power of the Central Government Budget. Working Paper 2000/6. Institut d'Economía de Barcelona.

Beck, N. and J. Katz. 1995. "What to do and not to do with Time-Series Cross-Section Data." American Political Science Review 89 (3): 634-647.

Bennett, J. T., and E. R. Mayberry. 1979. "Federal Tax Burdens and Grant Benefits to States: The Impact of Imperfect Representation." Public Choice 34 (3): 255-269.

Beramendi, P. 2008. "Inequality, Representation, and Endogenous Fiscal Institutions." Paper Prepared for Presentation at the Comparative Politics Workshop, Department of Political Science, Stanford University, Stanford, CA, June 2.

Beramendi, P. 2012. The Political Geography of Inequality: Regions and Redistribution. Cambridge: Cambridge University Press.

Beramendi, P., and A. Díaz-Cayeros. 2008. "Distributive Tensions in Developing Federations." Paper Presented at the Annual Meeting of the American Political Science Association, Boston, MA.

Beramendi, P., A. Díaz-Cayeros, and M. Rogers. 2017. "Barriers Against the Egalitarian Turn." Latin American Research Review 52 (4): 529-551.

Bolton, P., and G. Roland. 1997. "The Breakup of Nations: A Political Economy Analysis." The Quarterly Journal of Economics 112 (4): 1057-1090.

Bonvecchi, A., and G. Lodola. 2011. "The Dual Logic of Intergovernmental Transfers: Presidents, Governors, and the Politics of Coalition-Building in Argentina." Publius 41 (2): 179-206.

Calvo, E., and L. Moscovich. 2017. "Inequality, Protests, and the Progressive Allocation of Cash Transfers in the Argentine Provinces." Latin American Politics and Society 59 (2): 3-26.

Capello, M., A. Figueras, S. Freille, and P. Moncarz. 2009. "Fiscal Transfers, Public Sector Wage Premium and the Effects on Private Wages." Revista de Economía y Estadística 47 (2): 41-66.

Cappelen, A., F. Castellacci, F.J. Fagerberg, and B. Verspagen. 2003. "The Impact of EU Regional Support on Growth and Convergence in the European Union." Journal of Common Market Studies 41: 621-644.

Coulombe, S., and F. Lee. 1995. "Convergence Across Canadian Provinces, 1961 to 1991." Canadian Journal of Economics 28 (4): 886-898.

De Oliveira, J. 2008. "Análise do Crescimiento Económico e das Desigualdades Regionais no Brasil." Estudos do CEPE 28: 5-26.

Díaz-Cayeros, A. 2004. "El Federalismo y los Limites Políticos de la Redistribución." Gestión y Política Pública 3 (13): 663-687.

Elazar, D. 1991. Exploring Federalism. Tuscaloosa: University of Alabama Press.

Gervasoni, C. 2010. "A Rentier Theory of Subnational Regimes: Fiscal Federalism, Democracy, and Authoritarianism in the Argentine Provinces." World Politics 62 (2): 302-340. 
Gibson, E. 2005. "Boundary Control: Subnational Authoritarianism in Democratic Countries." World Politics 58 (1): 101-132.

Gibson, E., and E. Calvo. 2000. "Federalism and Low-maintenance Constituencies: Territorial Dimensions of Economic Reform in Argentina." Studies in Comparative International Development 35 (3): 32-55.

Hernández-Trillo, F. 2016. "Poverty Alleviation in Federal Systems: The Case of México." World Development 87: 204-214.

Holcombe, R., and A. Zardkoohi. 1981. "The Determinants of Federal Grants." Southern Economic Journal 48 (2): 393-399.

Kaufman, M., P. Swagel, and S. Dunaway. 2003. Regional Convergence and the Role of Federal Transfers in Canada. IMF Working Paper 03/97, 1-13.

Lijphart, A. 2012. Patterns of Democracy: Government Forms and Performance in ThirtySix Countries. New Haven, CT: Yale University Press.

Lowi, T. 1984. "Why is There no Socialism in the United States? A Federal Analysis." International Political Science Review 5 (4): 369-380.

Luke, D. 2004. Multilevel Modeling. Thousand Oaks, CA: Sage.

Lustig, N., L. F. Lopez-Calva, and E. Ortiz-Juarez. 2013. "Declining Inequality in Latin America in the 2000s: The Cases of Argentina, Brazil, and Mexico." World Development 44: 129-141.

Macdougall, D. 1977. Rapport du Groupe de Réflexion sur le Role des Finances Publiques dans I'Integration Européenne, Comission des Communautes Europeennes. Serie Economie et Finances, No. A13-B13.

Maciel, P., J. Andrade, and V. Kuhl. 2008. Transferências Fiscais e Convergência Regional no Brasil. Working Paper, Banco de Nordeste do Brasil.

Martinez-Vazquez, J., and A. Timofeev. 2010. Intra-regional Equalization and Growth in Russia. International Studies Program Working Papers 10-11.

Mélitz, J., and F. Zumer. 1998. "Redistribution Régionale et Stabilisation par le Gouvernement Central." Économie Internationale 75 (3): 3-31.

Obinger, H., S. Leibfried, and F. G. Castles. 2005. Federalism and the Welfare State: New World and European Experiences. Cambridge: Cambridge University Press.

O'Donnell, G. 1996. Poverty and Inequality in Latin America: Some Political Reflections. Kellogg Institute Working Paper 225.

Ramakrishnan, U., and M. Cerisola. 2004. Regional Economic Disparities in Australia. IMF Working Paper 04/144.

Rangarajan, C., and D. Srivastava. 2004. Fiscal Transfer in Australia: Review and Relevance to India. Working Papers 04/20. National Institute of Public Finance and Policy.

Rao, M., and N. Singh. 2001. The Political Economy of Center-State Fiscal Transfers in India. Working Paper 107. Stanford, CA: Center for Research on Economic Development and Policy Reform, Stanford University.

Remmer, K. 2007. "The Political Economy of Patronage: Expenditure Patterns in the Argentine Provinces, 1983-2003." The Journal of Politics 62 (2): 363-377.

Rodden, J. 2004. "Comparative Federalism and Decentralization. On Meaning and Measurement." Comparative Politics 36 (4): 481-500.

Rodden, J. 2006. Hamilton's Paradox: The Promise and Peril of Fiscal Federalism. Cambridge: Cambridge University Press.

Rodden, J. 2009. Federalism and Inter-regional Redistribution. Document de Treball de I'IEB 2009/3.

Rodden, J., and E. Wibbels. 2002. "Beyond the Fiction of Federalism: Macroeconomic Management in Multitiered Systems." World Politics 54 (4): 494-531. 
Rodríguez, G. 2006. "The Role of the Interprovincial Transfers in the ß: Further Empirical Evidence for Canada." Journal of Economic Studies 33 (1): 12-29.

Samuels, D. 2003. Ambition, Federalism, and Legislative Politics in Brazil. Cambridge: Cambridge University Press.

Samuels, D., and F. Abrucio. 1997. "The New Politics of the Governors: Subnational Politics and the Brazilian Transition to Democracy." Paper Presented at the Meeting of the International Political Science Association in Seoul.

Samuels, D., and R. Snyder. 2001. "The Value of a Vote: Malapportionment in Comparative Perspective." British Journal of Political Science 31 (4): 651-671.

Smith, H., and K. Revell. 2016. "Micro-incentives and Municipal Behavior: Political Decentralization and Fiscal Federalism in Argentina and Mexico." World Development 77: 231-248.

Stepan, A. 2005. "Federalism and Democracy: Beyond the US Model." In Theories of Federalism: A Reader, edited by D. Karmis and W. Norman, 255-268. London and New York: Palgrave Macmillan.

Tiebout, C. 1956. "A Pure Theory of Local Expenditures." The Journal of Political Economy 64 (5): 416-424.

Treisman, D. 2007. The Architecture of Government: Rethinking Political Decentralization. Cambridge: Cambridge University Press.

Tsebelis, G. 2002. Veto Players: How Political Institutions Work. Princeton, NJ: Princeton University Press.

Weingast, B. 1995. "The Economic Role of Political Institutions: Market-Preserving Federalism and Economic Growth." Journal of Law, Economics, and Organization 11 (1): 1-31.

Wibbels, E. 2005. "Decentralized Governance, Constitution Formation, and Redistribution." Constitutional Political Economy 16: 161-188.

Wildavsky, A. 1984. "Federalism Means Inequality: Geometry, Political Sociology, and Political Culture." In The Costs of Federalism, edited by R. Golembiewski and A. Wildavsky, 55-69. New Brunswick/London: Transaction Books. 